\title{
Revision of the genus Macropsobrycon Eigenmann, 1915 (Characidae: Cheirodontinae: Compsurini)
}

\author{
Fernando C. Jerep ${ }^{1}$ and Luiz R. Malabarba ${ }^{2}$
}

The cheirodontine genus Macropsobrycon is redefined and considered monotypic. The type species, M. uruguayanae, is redescribed based on samples from the entire known geographical distribution of the species. Sexually dimorphic characters of M. uruguayanae are further described and the relationships of the species with the remaining Compsurini are discussed.

O gênero Macropsobrycon de Cheirodontinae é redefinido e considerado monotípico. A espécie-tipo, M. uruguayanae, é redescrita com base em amostras de toda a distribuição geográfica conhecida da espécie. Caracteres de dimorfismo sexual secundário de M. uruguayanae são descritos e as relações da espécie com outros Compsurini são discutidas.

Key words: Neotropical, Sexual dimorphism, Systematics, Taxonomy.

\section{Introduction}

Historical review. Eigenmann(1915) described Macropsobrycon, containing a single species, M. uruguayanae, in the subfamily Cheirodontinae. In the Eigenmann's early concept of this subfamily (now corresponding to Aphyocharacinae + Aphyoditeinae + Cheirodontinae + Paragoniatinae + some Tetragonopterinae characid genera sensu Mirande, 2010), the Cheirodontinae diagnosis was presented in a topic "Generalized type of the subfamily" in which he referred the conspicuous small body size, the single tooth series, and the teeth with "lateral notches" [cusps] to these characids. Actually, the multicuspid teeth and the presence of one tooth series in the premaxilla and dentary have been the main characters used in subsequent years to diagnose the Cheirodontinae among characids (Eigenmann, 1915). In the end of the description of M. uruguayanae, notably Eigenmann considered that its conical teeth would "place it outside the subfamily", but also stated that its relationships [to Cheirodontinae] are "unmistakable". He further considered Macropsobrycon related to Parecbasis Eigenmann, Aphyodite Eigenmann, Leptobrycon Eigenmann, and possibly to some Megalamphodus Eigenmann, all genera currently removed from Cheirodontinae (Malabarba, 1998), differing from Parecbasis by having fainter dentition and incomplete lateral line, from Aphyodite by having the caudal fin naked and well developed pseudotympanum, and from Leptobrycon by having the anal fin longer. Although consistent, Eigenmann's description was incomplete in some aspects as the color pattern of the dorsal and anal fins, and neither mentioned the complex caudal-fin structures present on mature males. He still affirmed that scales were "apparently absent from caudal" causing uncertainty about the presence of them on the caudal fin.

Géry (1960), reviewing the morphological affinities of some Cheirodontinae, placed Macropsobrycon in an "intermediate section" of the subfamily, jointly with 13 genera characterized by the presence of slender conical or tricuspid teeth, fourth infraorbital not developed, and presence of an adipose fin. In this work, Géry split this "section" in three smaller groups, situating Macropsobrycon with some other "degenetrate or specialized species" of the genera Parecbasis, Leptobrycon, Aphyodite, and Thrissobrycon Böhlke, based on the shared presence of an elongated body, conical teeth reduced in number and size (at least on the maxilla), and a thicker and blade-like maxilla. Géry still briefly distinguished Macropsobrycon from these other genera by the presence of a superior mouth, postorbitals (infraorbitals 4 and 5) not developed, fontanels short, lateral line incomplete, caudal naked, pseudotympanum

${ }^{1}$ Pontifícia Universidade Católica do Rio Grande do Sul, Laboratório de Sistemática de Vertebrados, Setor de Ictiologia, Museu de Ciências e Tecnologia. Av. Ipiranga 6681, 90619-900 Porto Alegre, RS, Brazil. fjerep@gmail.com

${ }^{2}$ Universidade Federal do Rio Grande do Sul, Laboratório de Ictiologia, Departamento de Zoologia e Programa de Pós-Graduação em Biologia Animal, IB, UFRGS, Porto Alegre, RS, Brazil. malabarb@ufrgs.br 
and some interhaemals (caudal-fin procurrent rays) present; and described the shape of the Macropsobrycon premaxilla and mesethmoid (dermethmoid in that paper) bones as identical to those of the representatives of the "tricuspid cheirodontines" group, where the premaxilla is asymmetric with a high ascending process and low horizontal process, and the mesethmoid pointed.

Géry (1965) also included Macropsobrycon in his phenetic diagram with the representatives of the sub-tribe Aphyoditeini, suggesting that the genus could be the "junction" between the subgroup formed by Prodontocharax Eigenmann \& Pearson, Hyphessobrycon stigmatias Fowler, and Microschemobrycon Eigenmann; and the subgroups formed by Aphyodite, Brittanichthys, Leptobrycon, and Parecbasis Géry. Later on, Géry (1972) proposed an updated phenetic diagram for the Aphyoditeini, where Macropsobrycon was grouped with Aphyodite representing a major group with Brittanichthys, Leptobrycon and Thrissobrycon. In this work, Géry also emphasized the differences between Aphyocharax melanotus [sic] and Macropsobrycon uruguayanae, disagreeing with Eigenmann's (1915) suggestion about a possible close relationship between these species, and proposed the new combination Microschemobrycon melanotus (Eigenmann).

The genus remained monotypic up to Géry (1973) description of Macropsobrycon xinguensis in a revisionary study of the "Aphyoditeina" species from the Amazon basin. Géry (1973) quoted several differences between $M$. uruguayanae and $M$. xinguensis, like, for instance, the absence of a humeral hiatus in his new species, as well as the presence of partially scaled caudal-fin lobes, tricuspid teeth (vs. conical), dorsal-fin in front of mid-body, number of branched anal-fin rays (17-18 vs. 19-22 in M. uruguayanae), number of perforated lateral line scales ( 8 vs. 5-6 in M. uruguayanae), and a different caudal color pattern. The placement of the new species in Macropsobrycon was considered by Géry a "conservative solution", taken "provisorily", once both species have similar characters like feeble teeth, toothless maxilla and incomplete pored lateral line. Géry (1977) arranged the Cheirodontinae in two major groups: the Cheirodontinae sensu stricto, and the "allied genera". The group represented by the "allied genera" was split in three tribes: Grundulini, Henochilini, and Probolodini. His former Aphyoditeina, including the Macropsobrycon species, was now treated as the "Aphyoditegroup", inside the tribe Grundulini together with the Grundulusgroup and the Pristella-group.

Reprodutive biology. Little was known about the biology and reproductive characters of Macropsobrycon up to Burns et al. (1997) analysed histological sections of Macropsobrycon uruguayanae, as well as of some other cheirodontines, and found $M$. uruguayanae to be inseminating, presenting elongated spermatozoa. Burns et al. (1998) carried out transmission electron microscopy on some inseminating characid species belonging to the subfamilies Aphyocharacinae, Glandulocaudinae (now part of
Stevardiinae sensu Mirande, 2010), and Cheirodontinae, represented by M. uruguayanae. The same authors described briefly the spermatozoa ultrastructure of M. uruguayanae, and through new ultrastructural characters supported Malabarba's (1998) hypothesis of independent development of insemination in the Glandulocaudinae and in the inseminating Cheirodontinae (now Compsurini). Later on, the sperm ultrastructure of Macropsobrycon uruguayanae was described in detail by Oliveira et al. (2008), and its reproductive biology and gill gland development by Azevedo et al. (2010), making M. uruguayanae the best known cheirodontine in terms of reproductive aspects to date.

Systematics and relationships. In a phylogenetic study, Malabarba (1998) defined Cheirodontinae sensu stricto and demonstrated cladistically that in the former systematic arrangement of the subfamily the species were artificially grouped, and several genera and species were then removed from that taxon. Macropsobrycon uruguayanae, sharing the main synapomorphies with the other members of the subfamily, was kept in the more restricted group of the Cheirodontinae as part of a new inseminating tribe, Compsurini. On the other hand, M. xinguensis was considered species incertae sedis in Characidae, since it does not present all of the synapomorphies of the subfamily (Malabarba, 1998; Reis et al., 2003). The genus Macropsobrycon was further diagnosed by Malabarba (1998) based on four characters: (1) presence of a large space bearing hypertrophied tissue between the twelfth and thirteenth caudal-fin rays; (2) small and flexible spines present along the proximal portion of the lower lobe principal caudal-fin rays; (3) jaw teeth elongated and conical or tricuspid [modified herein, see diagnosis of Macropsobrycon]; and (4) the dorsal-fin strongly blackpigmented along the mid-length of the second unbranched and first 5 branched rays [modified herein, see diagnosis of Macropsobrycon], and weakly pigmented along their distal portion.

Secondary sexual characters of $M$. uruguayanae have been briefly discussed by Malabarba \& Weitzman $(1999,2000)$ and Malabarba et al. (2004) in comparison to Acinocheirodon melanogramma Malabarba \& Weitzman, Kolpotocheirodon theloura Malabarba \& Weitzman, and Kolpotocheirodon figueiredoi Malabarba, Lima \& Weitzman, respectively.

Mirande $(2009,2010)$ proposed a hypothesis of relationships among characid representatives and a new classification. Although the genus Macropsobrycon was kept in Cheirodontinae, none of its species were included in his analysis. Most recently, Javonillo et al. (2010) developed a phylogenetic study within the Characidae based on molecular sequenced data of a number of genera and species. The results showed $M$. uruguayanae as part of the Cheirodontinae in accordance with previous phylogenetic analysis based on morphological data, and M. xinguensis as sister group of Hyphessobrycon herbertaxelrodi Géry, inside a large clade including several incertae sedis Characidae genera distant from the Cheirodontinae clade. 
Despite of the works regarding the relationships and reproductive biology of Macropsobrycon uruguayanae, the range of its geographical distribution, its morphological variation, and the secondary sexual dimorphism on its caudal fin, were never assessed. Macropsobrycon uruguayanae was described based on six specimens collected by Haseman in the rio Uruguay basin [Uruguaiana and Cacequi, Rio Grande do Sul State], nevertheless the species has been collected in an wider geographical range, encompassing the rio Negro basin (a tributary on the lower part of rio Uruguay), and the laguna dos Patos system in Rio Grande do Sul, Brazil and Uruguay. It is often misidentified as the Heterocheirodon species, which present the same geographical distribution and similar body shape. Herein the genus Macropsobrycon is redefined, and its type species M. uruguayanae redescribed based on specimens from all its geographical range, which allowed the study of the morphological variation among populations from different drainages. The secondary sexual characters found in the caudal fin of mature males are detailed reviewed and firstly described.

\section{Material and Methods}

Counts and measurements were taken according to Fink \& Weitzman (1974), whenever possible on the left side of the specimens. Measures were taken point-to-point straight-line with a 0.01 precision caliper. Head length is defined as the distance between the tip of the snout and the posterior margin of subopercle (Bührnheim \& Malabarba, 2006). Total vertebrae number includes the four vertebrae of the Weberian apparatus, and the terminal "half centrum" (Malabarba \& Weitzman, 1999). Gill rakers were counted on first branchial arch, and the gill raker located at the junction of the ceratobranchial and the epibranchial was referred to the epibranchial count. The counts of vertebrae, supraneurals, teeth, and gill rakers were based on radiographs and cleared and stained (c\&s) specimens following Taylor \& van Dyke (1985) protocol. Scanning Electron Microscope (SEM) images were obtained from the jaws. Drawings of the anal fin, caudal fin, and scales were prepared in a stereomicroscope with camera lucida.

Sex identification of specimens was based on Gonçalves et al. (2005) and Bührnheim \& Malabarba (2006), where males and females are recognized by dissection, or by the presence of sexual dimorphism, like anal and caudal-fin hooks, in specimens with similar size in the same sample. Specimens smaller than the smallest specimen showing sexual dimorphism in each lot are termed as unsexed, as well as specimens belonging to lots where sexual dimorphism is absent.

The redescription and the statistical and histological analysis were based on specimens from museum collections listed in the material examined, which abbreviations are: ANSP - Academy of Natural Sciences of Philadelphia, Philadelphia, USA; CAS - California Academy of Sciences, San Francisco, USA; FMNH - Field Museum of Natural History, Chicago, USA; MCP - Museu de Ciências e Tecnologia da PUCRS, Porto Alegre, Brazil; MZUSP - Museu de Zoologia da
Universidade de São Paulo, São Paulo, Brazil; UFRGS Universidade Federal do Rio Grande do Sul, Porto Alegre, Brazil; and USNM - National Museum of Natural History, Smithsonian Institution, Washington D.C., USA. Other abbreviations are given along with the number of specimens: $\mathrm{m}$ - morphometric and meristic.

Statistical analyses. Principal Component Analysis (PCA) was used to investigate morphometric variation among Macropsobrycon uruguayanae populations from three river basins: rio Uruguay basin, rio Negro basin (a tributary of the lower rio Uruguay), and laguna dos Patos basin. The program PAST version 2.04 (Hammer et al., 2001) was used for PCA analysis, the measures were logarithmically transformed. Considering that generally the first principal component mostly accounts for size variation (Strauss, 1985), a linear correlation was performed between the PC1 scores and the standard length values of the analysed specimens to test this hypothesis. A simple Multivariate Analysis of Variance (MANOVA) on the PC2 and PC3 scores, grouped by drainage, was also performed. The morphometric variable "dorsal-fin length" was not included on the PCA analysis once this data was missing for several specimens with the dorsal fin broken.

\section{Results}

\section{Macropsobrycon Eigenmann, 1915}

Macropsobrycon Eigenmann, 1915: 16 [key to Cheirodontinae species]; 48 [diagnosis; type species by original designation and monotypy: Macropsobrycon uruguayanae Eigenmann, 1915:]. -Géry, 1960: 2, 5, 9, 14 [placement in an unnamed group of degenerated of very specialized species with reduced conical teeth]. -Géry, 1965 [listed in a new subtribe of Cheirodontidi [sic], the Aphyoditeini]. -Géry, 1972: 15-18 [inclusion in Aphyoditeini]. -Géry, 1977: 594 [in key to Aphyoditeina genera and species]. -Malabarba, 1998: 218 [phylogenetic diagnosis and relationships to cheirodontine genera; included in the new tribe Compsurini]. -Malabarba \& Weitzman, 1999: 424 [comparison with Acinocheirodon melanogramma]. -Malabarba et al., 2003: 217 [listed in Cheirodontinae]. -Mirande, 2009: 8, 11 [listed as Cheirodontinae]. -Javonillo et al., 2010: 505-507 [relationships within Characidae]. -Mirande, 2010: 528, 531532 [listed as Cheirodontinae].

Diagnosis. Distinguished from other genera of the Compsurini by the jaw teeth elongate and conical or rarely bicuspid. Macropsobrycon is further diagnosed from all characid species except the Cheirodontinae by the presence of cheirodontine synapomorphies (see discussion), and from all cheirodontine genera by the following autapomorphies: (1) a small and elongate black spot is present on the proximal half of the second unbranched dorsal-fin ray, corresponding 
to the distal half of the first unbranched dorsal-fin ray, sometimes extending over the first unbranched ray and corresponding region of the first branched ray [modified from Malabarba, 1998; originally stated as, black pigmentation along the mid-length of the second unbranched and first 5 branched rays]; (2) presence of a small black spot on the base of unbranched anal-fin rays; (3) Ppresence of a hypertrophied caudal-fin scale on ventral lobe of mature males; (4) $12^{\text {th }}$ and $13^{\text {th }}$ principal caudal-fin rays of males with robust retrorse hooks anteriorly directed at their branched portion; (5) $14^{\text {th }}$ to $18^{\text {th }}$ principal caudal-fin rays of males with feeble and flexible spinelets along their proximal length, and harder and anteriorly directed spinelets along its distal length; (6) $12^{\text {th }}$ and $13^{\text {th }}$ principal caudal-fin rays of males distant from each other, with the fin membrane between these contiguous rays bearing hypertrophied tissues.

\section{Macropsobrycon uruguayanae Eigenmann, 1915 Figs. 1-7}

Macropsobrycon uruguayanae Eigenmann, 1915: 48 [original description; dentition figured; type locality Uruguayana (Uruguaiana) and Cacequi, Rio Grande do Sul, Brazil, rio Uruguay drainage]. -Henn, 1928: 59 [type material listed from Carnegie Museum]. -Ibarra \& Stewart, 1987: 54 [type material listed from Field Museum of Natural History]. Ringuelet, 1967 [listed as freshwater fish from Argentina]. -Géry, 1972: 15-18 [inclusion in Aphyoditeini]. -Géry, 1973: 108-109 [compared to Macropsobrycon xinguensis]. -Géry, 1977: 594 [in key to Aphyoditeina genera and species]. Malabarba 1989: 136 [listed to laguna dos Patos drainage]. -Burns et al., 1997: 434 [listed as inseminating species]. Malabarba, 1998: 218 [phylogenetic diagnosis of the genus and placement in Compsurini]. -Burns et al., 1998: 242 [short description of sperm ultrastructure]. -Malabarba \& Weitzman, 1999: 416, 427 [comparison with
Acinocheirodon melanogramma]. -Malabarba \& Weitzman, 2000: 270, 279-280 [comparison with Kolpotocheirodon theloura]. -López et al., 2003: 31 [listed from Argentina]. -Malabarba et al., 2003: 217 [listed in Cheirodontinae]. -Quagio-Grassiotto et al., 2003: 41 [sperm morphology compared to other characiforms]. -Menni, 2004: 78 [listed from Argentina]. -Malabarba et al., 2004: 324-325 [comparison with Kolpotocheirodon figueiredoi]. -Malabarba, 2007: 37 [listed in Cheirodontinae]. -Pecio et al., 2007: 458 [sperm morphology compared along with other inseminating characids]. -Oliveira et al., 2008: 691697 [description of sperm ultrastructure and comparison to inseminating characids]. -Bührnheim et al., 2008: 671 [referred as bearing conical teeth]. -Miquelarena et al., 2008: 78 [listed from Argentina]. -Javonillo et al., 2010: 505-507 [relationships within Characidae]. -Azevedo et al., 2010: 87-96 [reproductive biology and gill gland development].

Diagnosis. Same as the genus.

Description. Morphometrics given in Table 1. Body slightly elongate and compressed, deepest at dorsal-fin origin. Dorsal profile convex from snout tip to dorsal-fin origin, straight or slightly convex from that point to adipose-fin origin. Ventral profile convex from snout tip to pelvic-fin insertion, straight or somewhat concave up to anal-fin origin, straight to convex on anal-fin base. Caudal-peduncle profile slightly concave dorsally and ventrally. Snout short, mouth superior above horizontal line projected through pupil dorsal border and below horizontal line projected through orbit dorsal edge.

Premaxilla slender with 3(1), 4(1), 5(11), 6(14) or 7(4) conical teeth, aligned and similar in size; ascending process wide and square shaped. Maxilla toothless, wide, arched, with distal tip reaching or surpassing vertical line projected through orbit anterior edge. Dentary with 4(2), 5(8), 6(13), 7(4), 8(2) or 10(2)

Table 1. Morphometric data of Macropsobrycon uruguayanae. $\mathrm{SD}=$ standard deviation.

\begin{tabular}{|c|c|c|c|c|c|c|}
\hline & Holotype & $\mathrm{N}$ & Min & Max & Mean & SD \\
\hline Standard length $(\mathrm{mm})$ & 36.1 & 121 & 28.0 & 40.6 & 32.9 & - \\
\hline \multicolumn{7}{|c|}{ Percents of Standard length } \\
\hline Head length & 23.5 & 121 & 21.3 & 27.3 & 24.2 & 1.1 \\
\hline Bony head length & 20.3 & 121 & 19.0 & 24.1 & 21.7 & 0.8 \\
\hline Snout-anal fin distance & 62.9 & 121 & 59.2 & 65.9 & 62.6 & 1.5 \\
\hline Snout-dorsal fin distance & 53.4 & 121 & 50.3 & 56.9 & 54.2 & 1.3 \\
\hline Snout-pelvic fin distance & 46.6 & 121 & 42.4 & 49.8 & 45.6 & 1.3 \\
\hline Snout-pectoral fin distance & 25.4 & 121 & 24.5 & 29.5 & 26.8 & 1.0 \\
\hline Dorsal-fin base length & 12.1 & 120 & 10.4 & 14.2 & 12.4 & 0.7 \\
\hline Anal-fin base length & 28.9 & 121 & 22.7 & 28.9 & 26.0 & 1.4 \\
\hline Length of caudal peduncle & 14.6 & 121 & 13.9 & 18.6 & 16.2 & 1.0 \\
\hline Depth of caudal peduncle & 11.7 & 121 & 9.7 & 13.5 & 11.7 & 0.8 \\
\hline Body depth at dorsal-fin & 31.8 & 121 & 27.3 & 35.2 & 30.9 & 1.4 \\
\hline Dorsal-fin length & 25.6 & 113 & 23.3 & 30.1 & 26.5 & 1.2 \\
\hline Pelvic-fin length & 14.7 & 120 & 14.0 & 17.7 & 15.9 & 0.8 \\
\hline Pectoral-fin length & 23.3 & 120 & 19.5 & 25.9 & 22.4 & 1.3 \\
\hline \multicolumn{7}{|c|}{ Percents of Head length } \\
\hline Snout length & 23.6 & 121 & 20.2 & 28.6 & 23.8 & 1.6 \\
\hline Upper Jaw length & 36.6 & 121 & 29.3 & 38.5 & 34.5 & 1.8 \\
\hline Horizontal orbit diameter & 37.4 & 121 & 30.8 & 42.9 & 36.4 & 2.8 \\
\hline Interorbital width & 25.1 & 121 & 23.6 & 32.2 & 27.4 & 1.5 \\
\hline
\end{tabular}



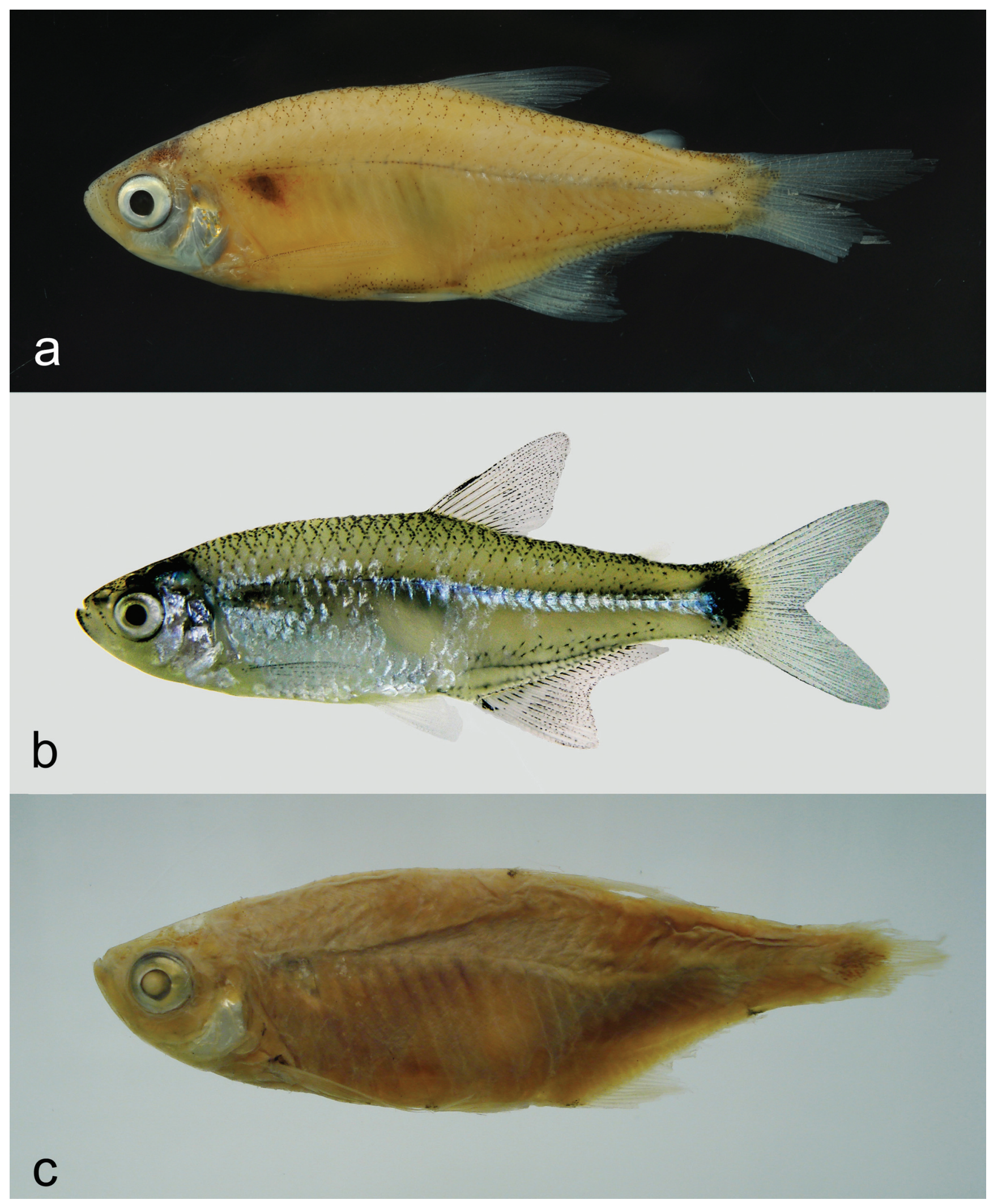

Fig. 1. Macropsobrycon uruguayanae, a - ANSP 168826, $32.8 \mathrm{~mm}$ SL, Uruguay, Depto. Cerro Largo, pool of rio Negro; b - specimen alive, not preserved; c - holotype, FMNH 57910, $36.0 \mathrm{~mm}$ SL, Brazil, Cacequy, rio Uruguay basin. 


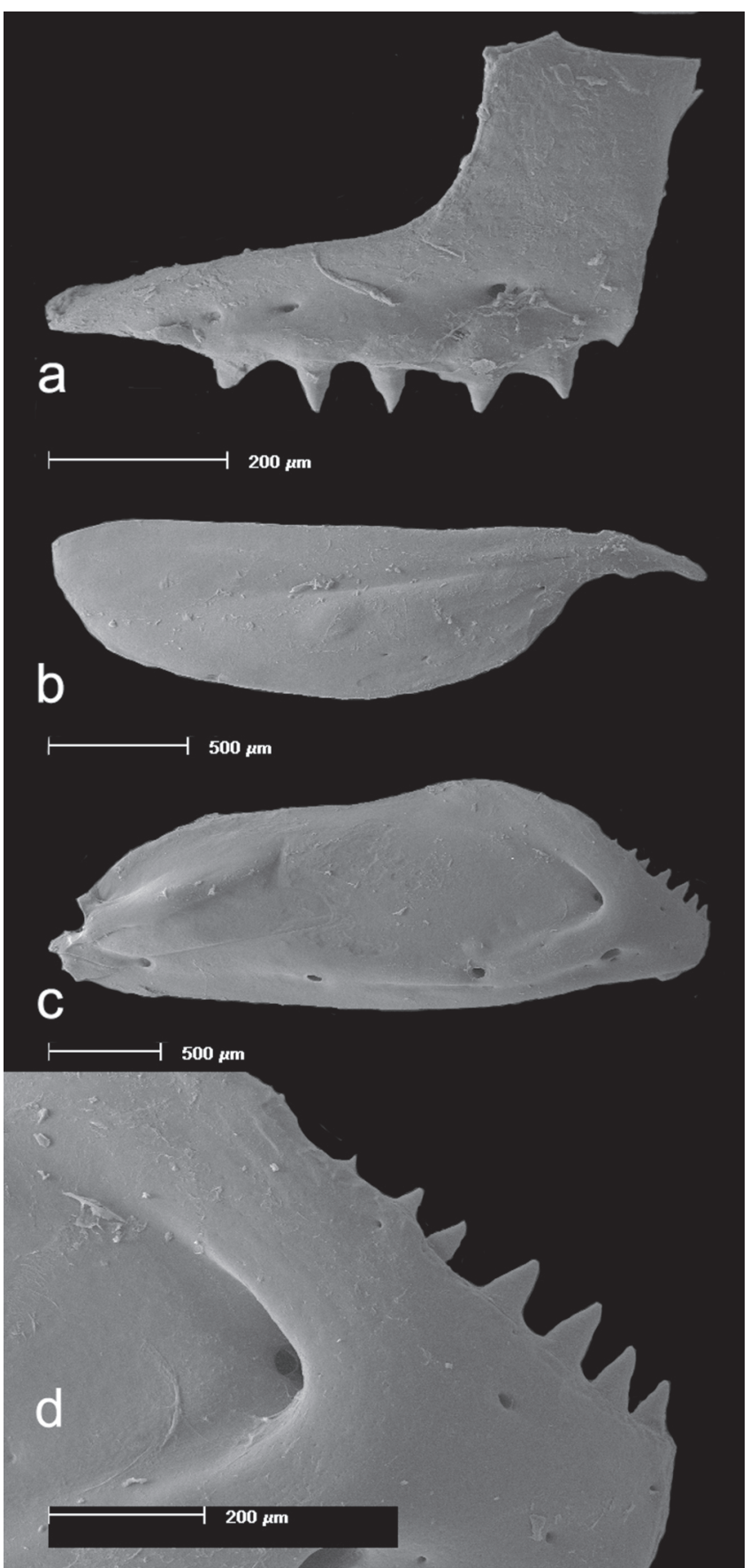

Fig. 2. Macropsobrycon uruguayanae, MCP 20900, $27.9 \mathrm{~mm}$ SL; Scanning Electron Microscopy (SEM) images showing $\mathbf{a}$ - right side premaxilla, $\mathbf{b}$ - maxilla , and $\mathbf{c}$ - dentary, with $\mathbf{d}$ detail of the teeth.

aligned teeth; teeth conical, rarely bicuspid; four medial teeth larger with similar size, following teeth smaller decreasing in size laterally (Fig. 2).

Dorsal-fin origin slightly posterior to vertical through middle of standard length. Dorsal-fin rays ii, $8-10$ (mean $=9.0$, $\mathrm{n}=120$ ). Adipose-fin origin at vertical line through last analfin ray insertion. Anal-fin origin slightly anterior to last dorsal- fin ray insertion; anterior rays longer than posterior ones; distal profile more convex on females than on males. Anal-fin rays iii-v, 17-22 (mean $=23.8, \mathrm{n}=121)$; last unbranched up to nineth anal-fin branched ray of mature or maturing males bearing small retrorse hooks (Fig. 3). Hooks placed from middle length to near the distal tip of anal-fin rays, attached at posterior margin and usually posterior branch in branched portion, bent over lateral surface, and directed anteriorly to anal-fin frontal margin. One or two hooks per anal-fin ray segment. Pectoral-fin rays i,10-12 (mean $=10.6, \mathrm{n}=121)$; longest rays surpassing pelvic-fin insertion. Pelvic-fin insertion anterior to vertical line through dorsal-fin origin. Pelvic-fin rays i,7; all of them bearing 1-2 unilateral ventromedial antrorse hooks per segment on mature males. Caudal fin with $18-20($ mean $=19.0, n=121)$ principal rays. Principal caudalfin rays $12^{\text {th }}$ and $13^{\text {th }}$ bearing recurved strong hooks anteriorly directed on branched portions, usually dorsally; principal caudal-fin rays $14^{\text {th }}$ to $18^{\text {th }}$ bearing posteriorly directed feeble spinelets along proximal portion, and anteriorly directed bony hooks along mid- and distal portions of fin rays on mature males (Fig. 4).

Lateral line incomplete, with 3-8 $($ mean $=6.1, \mathrm{n}=91)$ perforated scales. Total scales at lateral line series 30-37 (mean $=33.6, \mathrm{n}=120$ ) scales. Scale rows between dorsal-fin insertion and lateral line 5; scale rows between lateral line and pelvicfin insertion 2-4 $($ mean $=3.2, \mathrm{n}=121)$. Predorsal scales 10-16 $($ mean $=12.9, \mathrm{n}=119)$; postdorsal scales $7-10($ mean $=8.2, \mathrm{n}=$ $121)$; scales rows around caudal peduncle $12-14($ mean $=13.8$, $\mathrm{n}=121$ ). Last scales of lateral scale rows with higher radii number on adult males than other body scales. Last scale of scale row below lateral line larger and posteriorly hypertrophied on mature males, with distal margin reaching or slightly overlapping most proximal caudal-fin ray spinelets (Figs. 5-6).

Mature males with gill gland on first branchial arch (Fig. 7). Gill rakers of first branchial arch 1.5 times longer than rakers from remaining branchial arches, not bearing denticles, 3(2), 4(2) on hypobranchial, 13(3), 14(1) on ceratobranchial, 7(4) on epibranchial. Supraneurals 4(1), 5(15), 6(74), 7(115), 8(28), 9(2). Total vertebrae 29(1), 30(35), 31(179), 32(35). Precaudal vertebrae 12(4), 13(227), 14(20).

Pseudotympanum as large muscular hiatus between first and second pleural ribs, limited dorsally by the lateralis superficialis muscle, posteriorly by naked anterior face of second pleural rib, posteroventrally by obliquus inferioris muscle, anteroventrally by obliquus superioris muscle.

Color in alcohol. Overall body color varying from light yellow in fresh preserved specimens to pale brownish on old preserved specimens (Fig. 1a,c). Head black to dark brown dorsally. Region of infraorbitals 3-5 and opercular apparatus silver on freshly preserved specimens and yellow on older ones. Dark melanophores surround nares, lips, and anterior margin of orbit. Mental region dark due to high concentration of melanophores. Humeral spot absent. Dorsal and dorsolateral portion of body with melanophores distributed 


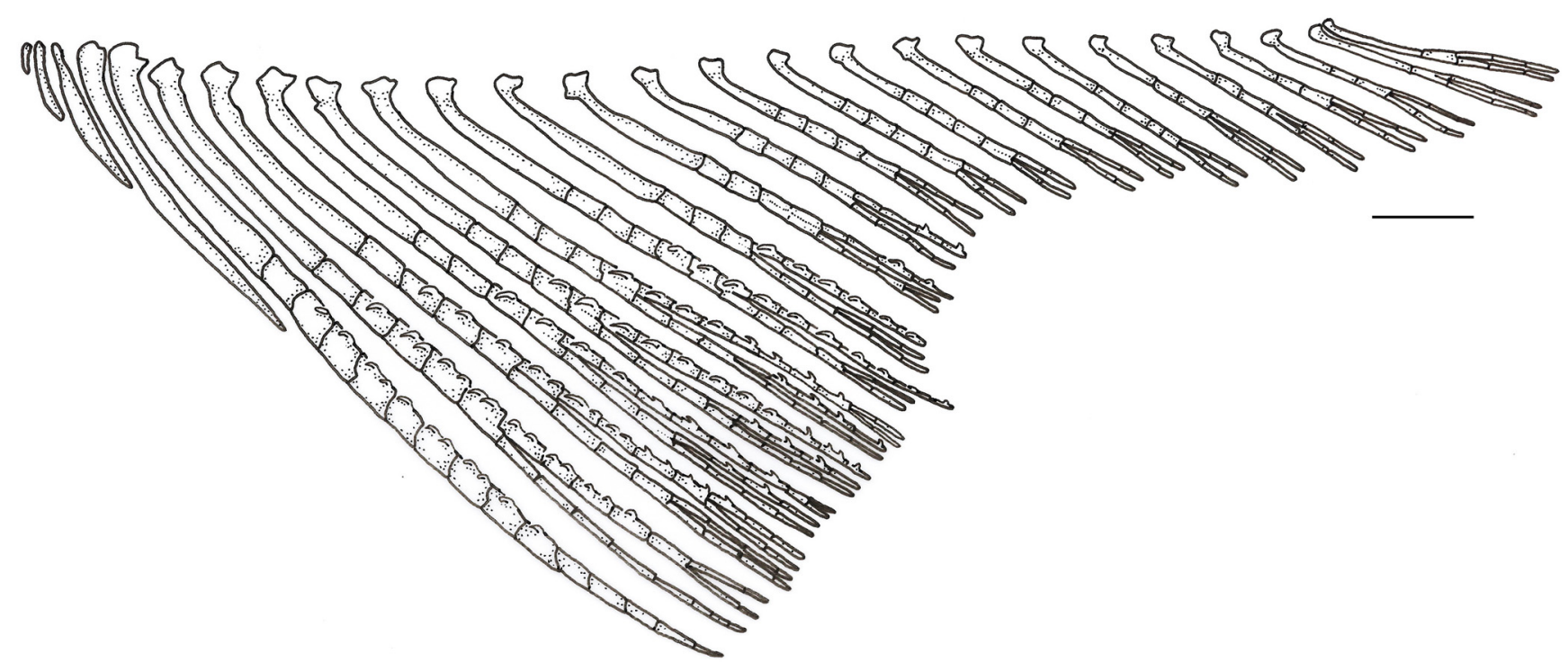

Fig. 3. Macropsobrycon uruguayanae, mature male, MCP 20900, $34.2 \mathrm{~mm}$ SL, left side lateral view of anal fin showing anal-fin hooks shape and distribution. Scale bar $=1 \mathrm{~mm}$.

at posterior margin of the scales. Thin dark line extending laterally on body, from posterior region of pseudotympanum to caudal spot. Posterior portion of this line sometimes silver. Caudal region with few melanophores distributed in oblique lines along myoseptum of epaxialis and hypaxialis muscles. Ventral region with higher concentration of melanophores around pelvic-fin insertion in mature males. All fins hyaline with scattered melanophores, except dorsal fin with a small elongated spot between distal tip of first unbranched ray and midpoint of second unbranched ray. Anal fin with an elongated small spot at base of unbranched anal-fin rays. Males with higher concentration of melanophores at distal margin of anal fin than females. Caudal spot round, not reaching dorsal and ventral margins of caudal peduncle, and not extending over middle caudal-fin rays; not conspicuous on some specimens.

Color in life. Overall body and head color pattern silver to white (Fig. 1b). Lateral body band silver. All the fins are hyaline

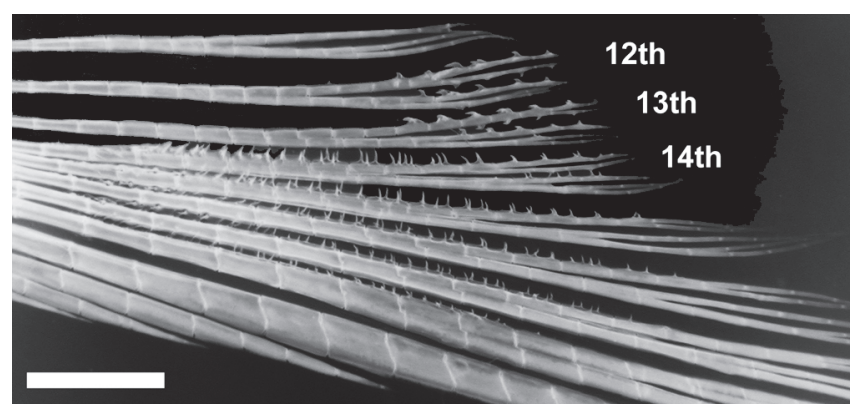

Fig. 4. Macropsobrycon uruguayanae, mature male, MCP $20900,34.2 \mathrm{~mm}$ SL, left side lateral view of the caudal-fin lower lobe, hook distribution. Scale bar $=1 \mathrm{~mm}$. with few scattered melanophores, and a small dark spot present at the dorsal and anal fin as described above.

Sexual dimorphism. Mature males can be differentiated from adult females by the presence hooks on pelvic, anal and caudal-fin rays (Figs. 3-5). Males also present the the gill filaments from the first branchial developed into a gill gland

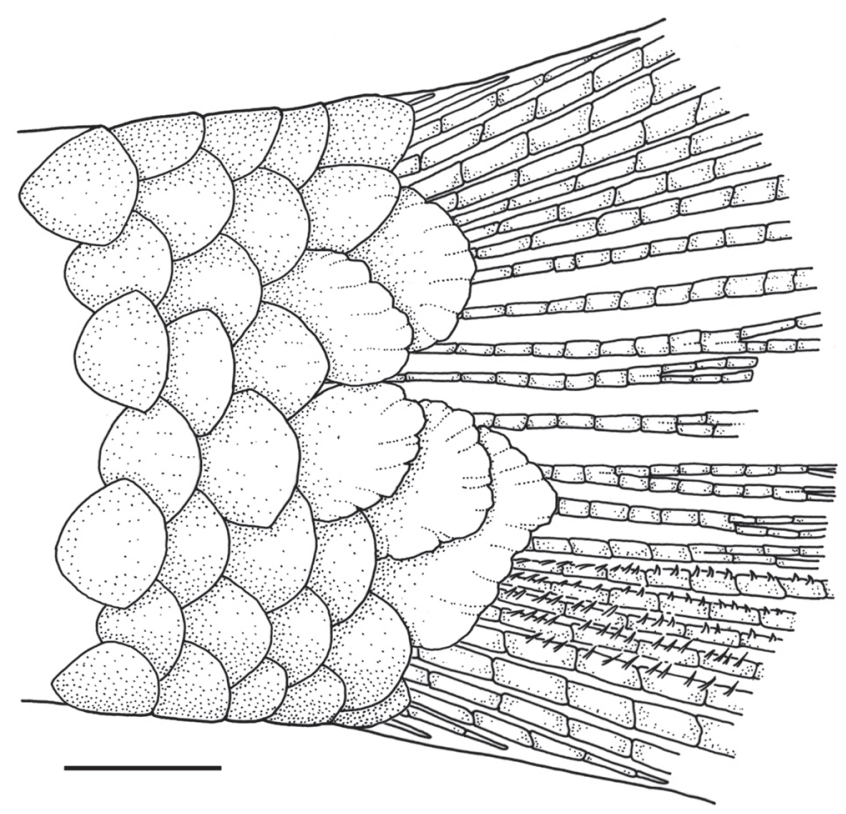

Fig. 5. Macropsobrycon uruguayanae, mature male, MCP $20900,34.2 \mathrm{~mm}$ SL, left side lateral view of the terminal portion of the caudal peduncle and caudal-fin base, showing modified scales and distribution of the "spinelets" on the caudal-fin rays. Scale bar $=1 \mathrm{~mm}$. 
(Fig. 7), due to the fusion of adjacent gill filaments by expansion of the epithelium that covers it (Azevedo et al., 2010). The last scale of the scale row below the lateral line is also larger and more developed in males than females (Fig. $6 b)$. Although the females also present a homologous scale relatively large when compared to other cheirodontine species, it is still smaller than that observed in males. Mature males also have a higher number of melanophores at the distal portion of the anal-fin rays forming a tenuous dark band along the distal margin of the anal fin that it is not seen in females. The ventral profile of the anal fin also differs between males and females, being less concave on males.

Habitat and ecological notes. Macropsobrycon uruguayanae is usually found in natural flooded ponds and/or small lagoons with direct and active connection to rivers or streams. This kind of habitat is strongly affected along the area of distribution of this species by its extensive use to rice cultivation. The species is inseminating with reproductive biology described in detail by Azevedo et al. (2010).

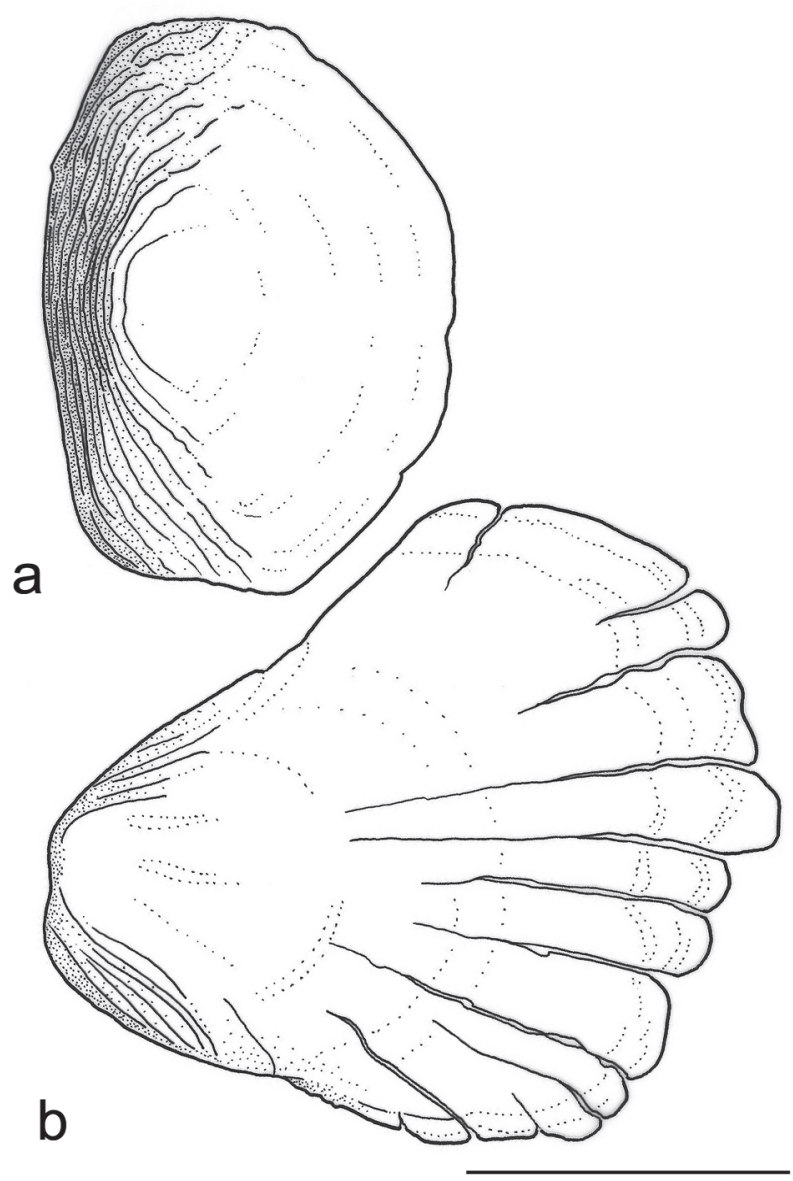

Fig. 6. Macropsobrycon uruguayanae, mature male, MCP 20900, $34.2 \mathrm{~mm}$ SL, left side, lateral view, a - lateral body scale and $\mathbf{b}$ - hypertrophied caudal-fin scale. Scale bar $=1 \mathrm{~mm}$.
Distribution and geographical variation. Records of Macropsobrycon uruguayanae are known from Rio Grande do Sul State in southern of Brazil, Província de Entre Ríos in Argentina (Demonte \& Arias, 2005; Miquelarena et al., 2008), and Uruguay. Its geographical distribution encompasses the rio Uruguay basin, rio Negro basin (large tributary of the lower rio Uruguay), and laguna dos Patos drainage (Fig. 8).

The PCA analysis provided some morphological differences among the populations from the three studied drainages. The principal component 1 represented $72.5 \%$ of the variance, however it was found a correlation of 0.96 between its scores and the standard length values, showing to be most affected by the size. The second and third principal component represented respectively $6.2 \%$ and $4.7 \%$ of the variance. The principal component 2 showed a trend of separation between the specimens from rio Negro and from rio Uruguay basins. The individuals from rio Negro presented relatively smaller snout length and trends to bigger horizontal orbit diameter than the rio Uruguay representatives. Morphological differences between Macropsobrycon uruguayanae from laguna dos Patos basin and rio Negro basin were evidenced by the principal component 3 . The laguna dos Patos basin specimens presented somewhat larger caudal peduncle length and upper jaw length, and relatively smaller anal-fin base length than specimens from rio Uruguay basin (Fig. 9). The MANOVA analysis of the PC2 and PC3 scores did not succeed in discrimitating the three populations.

Material analyzed: Macropsobrycon uruguayanae. Type material. Holotype: FMNH 57910, 36.0 mm SL, Brazil, Cacequy, 1 Feb 1909, J. D. Haseman. Paratypes: FMNH 57911, 4, 14.4-35.5 mm SL, Brazil, Cacequy, 1 Feb 1909, J. D. Haseman. FMNH 57912, 21.3 mm SL, Brazil, Cacequy, 5 Feb 1909, J. D. Haseman. Nontype material. Laguna dos Patos system, Brazil, Rio Grande do Sul: MCP 8421, 1 (m, male, 34.7 mm SL), arroio Capané at bridge on BR 290, tributary of rio Jacuí, 24 Oct 1982, C. A. S. Lucena \& L. R. Malabarba. MCP 9245, 6 (2m, males, 34.8-40.6 mm SL, 3, unsexed,

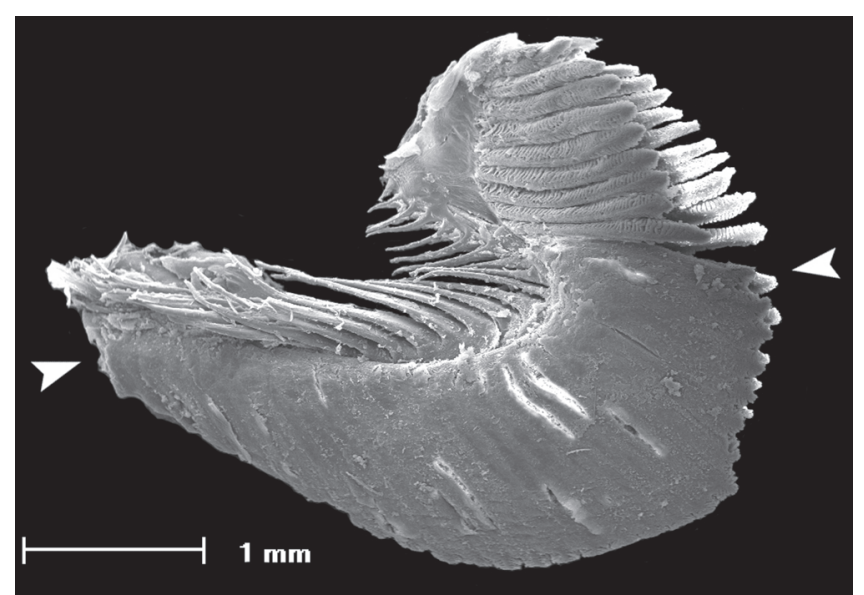

Fig. 7. Macropsobrycon uruguayanae, mature male, MCP 11939, 34.2 mm SL; Scanning Electron Micrograph (SEM) of the first gill arch left side, showing the gill gland delimited by the arrows head. 


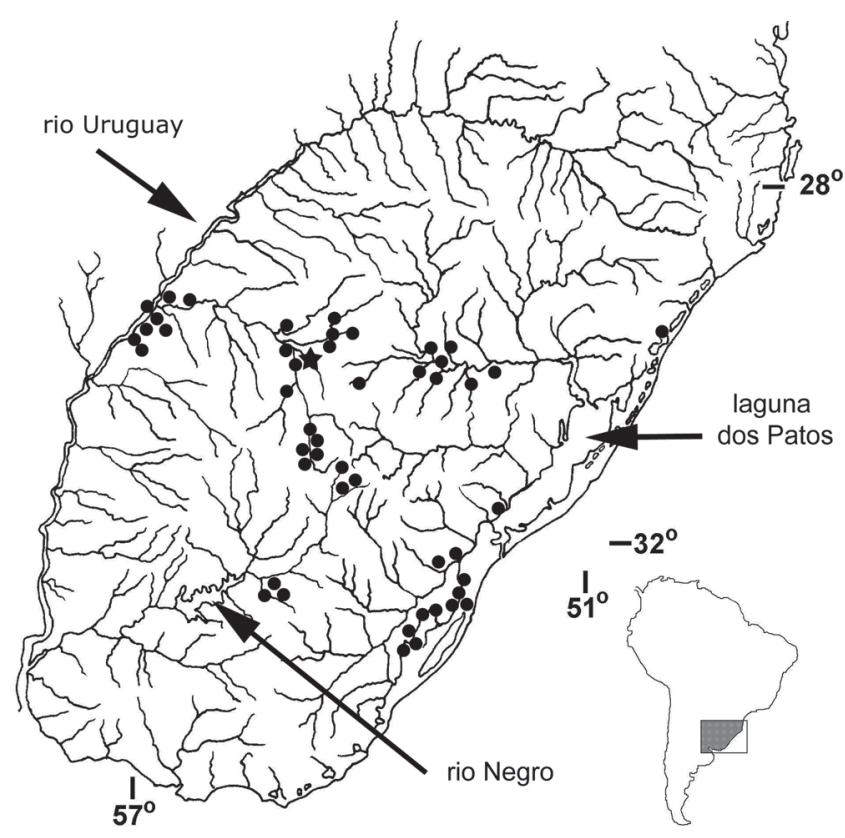

Fig. 8. Geographic distribution of Macropsobrycon uruguayanae, one dot can represent more than one locality. Star represents the type locality.

39.2-40.8 mm SL, 1 c\&s, 32.4 mm SL), backwater of rio Jacuí, road between Santa Maria and Vera Cruz, 16 Sep 1983, C. A. S. Lucena, L. R. Malabarba \& R. E. Reis. MCP 11997, 11 (4m, males, 32.4$39.8 \mathrm{~mm} \mathrm{SL}, 6 \mathrm{~m}$, females, 31.1-39.2 mm SL, 1, unsexed, $30.9 \mathrm{~mm}$ SL, 1 c\&s, female, $32.4 \mathrm{~mm} \mathrm{SL}$ ), arroio Francisquinho on highway BR 290 between Butiá and Rio Pardo, rio Jacuí basin, 24 Oct 1982, C. A. S. Lucena \& L. R. Malabarba. MCP 19410, 1 (unsexed, 22.3 $\mathrm{mm} \mathrm{SL}$ ), lakes on left margin of rio Jacuí, at bridge on road connecting BR 290 to Cachoeira do Sulpicaré, 22 Jan 1996, L. R. Malabarba, J. R. Burns \& J. F. Pezzi. MCP 20900, 87 (6m, males, 29.3-33.0 mm SL, 2m, females, 35.5-39.6 mm SL, 66, unsexed, 10.5-36.6 mm SL, 6 c\&s, males, 24.6-34.2 mm SL, 2 c\&s, females 33.2-35.1 mm SL, 1 c\&s, unsexed, $23.4 \mathrm{~mm} \mathrm{SL}$ ), stream on rio Jacuí basin, at bridge on road between São Gabriel and Tiarajupuçá, 14 Jan 1997, L. R. Malabarba, J. Alves Gomes \& V. Bertaco. MCP 37579, 2 (1m, male, $36.1 \mathrm{~mm}$ SL, 1m, female, $33.7 \mathrm{~mm} \mathrm{SL}$ ), Taim, Lago do Nicola, Jun 2004, A. Garcia. UFRGS 2244, 3 (unsexed, 22.9-24.7 mm SL) Rio Grande, Estação Ecológica do Taim, 8 May 1981, R. E. Reis \& J. R. Stehmann. UFRGS 2245, 2 (1m, female, 34.0, 1, unsexed, 33.2 $\mathrm{mm}$ SL), between Taim and Mirim, channel parallel to BR 471 near a pump building in Estação Ecológica do Taim, 21 Apr 1979, L. Jardim \& L. Chomenko. UFRGS 2306, $5 \mathrm{~m}$ (females, 30.7-36.4 mm SL), between Rio Grande and Mirim, right margin of BR 471 on Arroio Taim road, Estação Ecológica do Taim, 7 Dec 1979, N. A. Menezes et al. UFRGS 2307, 3m (females, 33.0-35.2 mm SL), same locality as UFRGS 2306, 7 Jul 1979, P. A. Buckup. UFRGS 5604, 5 (4m, males, 34.2-35.4 mm SL, 1m, female, 34.0 mm SL), Barra do Ribeiro, arroio Ribeiro, bridge on road to Barra do Ribeiro, 19 Oct 1999. USNM 268449, 3 (2m, males, 31.3-32.0 mm SL, 1m, female, $37.3 \mathrm{~mm} \mathrm{SL}$ ), arroio Sarandi at stream under road crossing on road between Pelotas and Jaguarão, tributary of lago Mirim North of arroio Grande, 14 Dec 1972, N. A. Menezes et al. Rio Negro basin, Brazil, Rio Grande do Sul: MCP 11932, 1 (unsexed,
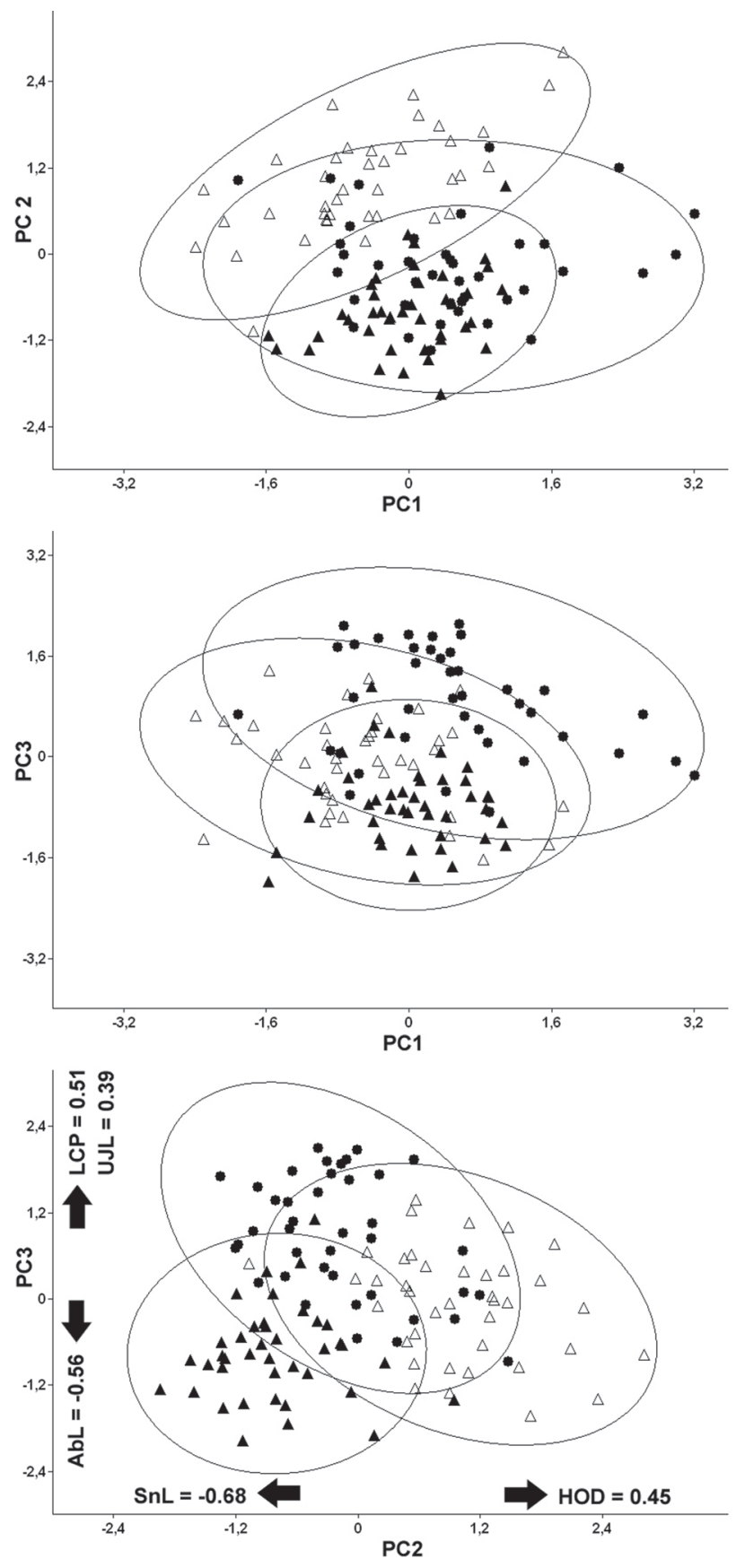

Fig. 9. Principal Component Analysis (PCA) of Macropsobrycon uruguayanae from three different basins: laguna dos Patos basin (dots), rio Uruguay basin (filled triangles), and rio Negro basin (empty triangles); based on the 18 morphometric variables listed in Table 1, except dorsal-fin length. Ellipses correspond to $95 \%$ confidence ellipses. The largest loadings are indicated on the second and third principal components (PC2, PC3), where $\mathrm{AbL}=$ anal-fin base length; $\mathrm{HOD}=$ horizontal orbit diameter; $\mathrm{LCP}=$ length of caudal-peduncle; $\mathrm{SnL}=$ snout length; UJL = upper jaw length. 
$25.4 \mathrm{~mm} \mathrm{SL}$ ), Bagé, arroio on BR $153 \mathrm{~km} 33$ between Bagé and Aceguá, 25 Oct 1982, C. A. S. Lucena \& L. R. Malabarba. MCP 11938, 6 (3m, males, 28.0-28.6 mm SL, 1 m, female, 31.0 mm SL, 2, unsexed, 19.5-23.4 mm SL) rio Negro, bridge on highway BR 293, between Bagé and Aceguá, 25 Oct 1982, C. A. S. Lucena, L. R. Malabarba. UFRGS 8383, 2 (1 $\mathrm{m}$, female, $38.9 \mathrm{~mm}$ SL, 1, unsexed, 25.5 mm SL) Bagé, sanga Cinco Salsos, BR 153 between Aceguá and Bagé, 29 Mar 2006, L. R. Malabarba et al. UFRGS 8430, 18 (8m, males, 30.6-32.4 mm SL, 3m, females, 28.2-34.8 mm SL, 5, unsexed, 28.2-31.3 mm SL, $1 \mathrm{c \& s}$, male, $31.3 \mathrm{~mm} \mathrm{SL}$ ), Bagé, rio Negro on highway BR 153 between Aceguá and Bagé, 29 Mar 2006, L. R. Malabarba et al. Uruguay, Cerro Largo: ANSP 168826, 20 (20.5-34.5 mm SL), Uruguay, Depto. Cerro Largo, pool at $10 \mathrm{~m}$ of rio Negro, Arreria, 19 may 1984, C. A. S. Lucena \& C. Chagas. MCP 11936, 120 (8m, males, 31.6-35.5 mm SL, 13m, females, 28.7-35.7 mm SL, 92, unsexed, 22.9-32.4 mm SL, 4 c\&s, males, 30.2-31.4 mm SL, 5 c\&s, females, 30.0-31.7 mm SL, 4 c\&s, unsexed, 21.5-25.6 mm SL), same data as ANSP 168826. Uruguay, Rivera: UFRGS 7277, 2 (1m, male, $31.2 \mathrm{~mm} \mathrm{SL}, 1 \mathrm{~m}$, female, $39.3 \mathrm{~mm} \mathrm{SL}$ ), rio Negro en el puente sobre la ruta 44, paso de Manzaneano, haci la ruta 26, 27 May 2005, L. R. Malabarba, V. A. Bertaco, P. Lehmann \& F. Cantina. Uruguay, Rio Negro: UFRGS 7421, 1 (m, female, $39.3 \mathrm{~mm} \mathrm{SL}$ ), on bridge in Pasos del Toros, rio Negro, 28 May 2005, L. R. Malabarba, V. A. Bertaco, P. Lehmann \& F. Cantuna. Rio Uruguay basin, Brazil, Rio Grande do Sul: MCP 11810, 1 (unsexed, $20.9 \mathrm{~mm} \mathrm{SL}$ ), rio Uruguay, 10 Nov 1987, J. Bertoletti, C. Lucena, E. Lerner \& P. Azevedo. MCP 11921, 4 (unsexed, 17.9$20.4 \mathrm{~mm} \mathrm{SL}$ ), rio Ibicuí-Mirim at rio Toropi mouth, 3 Jan 1983 , UFSM. MCP 11922, 4 (unsexed, 18.9-22.5 mm SL), rio IbicuíMirim at mouth on rio Santa Maria, 14 Jan 1983, UFSM. MCP 11923, 3 (unsexed, 24.1-36.7 mm SL), rio Ibicuí-Mirim on rio Toropi mouth, 3 Jan 1983, UFSM. MCP 11924, 1 (unsexed, 22.8 mm SL), rio Santa Maria, 26 Oct 1982, C. A. S. Lucena \& L. R. Malabarba. MCP 11925, 3 (unsexed, 32.7-35.1 mm SL), rio Ibicuí-Mirim on rio Santa Maria mouth, 14 Jan 1983, UFSM (Universidade Federal de Santa Maria). MCP 11926, 7 (6m, males, 28.4-32.2 mm SL, 1m, female, $32.2 \mathrm{~mm} \mathrm{SL}$ ), São Francisco de Assis, rio Jaguari, 15 Sep 1983, C. A. S. Lucena, L. R. Malabarba \& R. E. Reis. MCP 11927, 11 (unsexed, 24.6-35.9 mm SL), rio Ibicuí-Mirim, at road connecting Santa Maria to São Pedro, at $20 \mathrm{~km}$ far from Santa Maria, 20 Mar 1982, UFSM. MCP 11928, 36 (unsexed, 21.2-35.3 mm SL), rio Santa Maria, at BR 293, km 246, section Dom Pedrito/Santana do Livramento, 26 Oct 1982, C. A. S. Lucena \& L. R. Malabarba. MCP 11929, 16 (5m, males, 31.2-33.6 mm SL, 2m, females, 31.5-31.9 mm SL, 9, unsexed, 30.6-33.26 mm SL), sanga on road Santa Maria/ Mata, 13 Sep 1983, C. A. S. Lucena, L. R. Malabarba \& R. E. Reis. MCP 11930, 10 (unsexed, 25.5-32.0 mm SL), Ponto 2, 8 Apr 1983, UFSM. MCP 11931, 51 (unsexed, 21.4-33.5 mm SL), rio Santa Maria on BR 293, km 246, section Dom Pedrito/Santana do Livramento, 26 Oct 1982, C. A. S. Lucena \& L. R. Malabarba. MCP 11933, 1 (unsexed, $27.6 \mathrm{~mm} \mathrm{SL}$ ), rio Santa Maria, on BR 293, km 246, section Dom Pedrito/Santana do Livramento, 26 Oct 1982, C. A. S. Lucena \& L. R. Malabarba. MCP 11934, 5 (unsexed, 26.134.4 mm SL), rio Ibicuí-Mirim, 10 Jun 1986, UFSM. MCP 11935 , 6 (unsexed, 24.0-25.9 mm SL), Itaqui, mouth of rio Ibicuí at rio Uruguai, 19 Nov 1984, L. R. Malabarba \& R. E. Reis. MCP 11937, 208 (6m, males, 31.8-33.9 mm SL, 7m, females, 29.6-34.4 mm SL, 191, unsexed, 21.8-34.4 mm SL, 4 c\&s, males, 27.8-32.8 mm SL), rio Santa Maria on BR 293, km 246, section Dom Pedrito/Santana do Livramento, 26 Oct 1982, C. A. S. Lucena \& L. R. Malabarba. MCP 11939, 223 (219, unsexed, 21.4-34.8 mm SL, 1 c\&s, male, $30.1 \mathrm{~mm}$ SL, 3 c\&s, females, 32.4-35.1 mm SL), rio Santa Maria on
BR 293, km 246, section Dom Pedrito/Santana do Livramento, 26 Oct 1982, C. A. S. Lucena \& L. R. Malabarba. MCP 11998, 6 (1, males, 38.0 mm SL, 5, females, 36.5-44.6 mm SL), Santa Maria, pools on margin of rio Vacacai, 12 Sep 1983, C. A. S. Lucena, L. R. Malabarba \& R. E. Reis. MCP 14158, 4 (2, unsexed, 37.6-39.5 mm SL), arroio Santo Antonio, at road Rosário do Sul/Santana do Livramento, 13 Dec 1989, C. Weber, R. E. Reis \& S. Muller. MCP 14205, 1 (unsexed, $34.5 \mathrm{~mm} \mathrm{SL}$ ), pools on margin of rio Santa Maria, road Dom Pedrito/Santana do Livramento, 14 Dec 1989, C. Weber, R. E. Reis \& S. Muller. MCP 15336, 7 (unsexed, 26.2-28.4 mm SL), Uruguaiana, affluent of rio Uruguay at PUC, 26 Feb 1991, E. Q. Chiva. MCP 16393, 2 (unsexed, 21.0-26.2 mm SL), São Marcos, marginal lake on Formosa beach, affluent of rio Uruguay, 11 Dec 1992, P. H. Wimberger, R. E. Reis \& J. F. Pezzi. MCP 16399, 12 (unsexed, 20.9-28.8 mm SL), São Marcos, marginal lake on Formosa beach, affluent of rio Uruguay, 11 Dec 1992, P. H. Wimberger, R. E. Reis \& J. F. Pezzi. MCP 18365, 86 (1m, male, $32.8 \mathrm{~mm} \mathrm{SL}, 6 \mathrm{~m}$, females, 33.0-34.7 mm SL, 77, unsexed, 13.5-34.6 mm SL, 2 c\&s, females, 29.7-35.2 mm SL), São Marcos, marginal lake on Formosa beach, affluent of rio Uruguay, 21 Nov 1995, J. F. Pezzi, W. Santos, V. Bertaco \& C. Kohlmann. MCP 19602, 1 (unsexed, $27.7 \mathrm{~mm} \mathrm{SL}$ ), pool near Olaria on low land along side rio Santa Maria, BR 290, 15 Jan 1997, L. R. Malabarba, J. Alves Gomes \& V. Bertaco. MCP 23660, 7 (2m, males, 31.3-31.6 mm SL, 4m, females, 30.2-32.7 mm SL, 1, unsexed, $28.0 \mathrm{~mm} \mathrm{SL}$ ), Uruguaiana, Sanchuri dam, 21 Jul 1999, R. C. Beheregaray. MCP 40723, 1 (unsexed, $20.9 \mathrm{~mm} \mathrm{SL}$ ), rio Touro Passo, 17 Oct 1985, C. A. S. Lucena, C. Mardini \& C. Porto.

\section{Discussion}

\section{Relationships and characters defining Macropsobrycon}

Macropsobrycon uruguayanae presents most of the synapomorphies described by Malabarba (1998) to diagnose the Cheirodontinae: the peculiar pseudotympanum (see Ch. 1 of Malabarba 1998: 199), the lack of a humeral spot, and a single tooth row with teeth aligned and similar in shape and cusp number. The absence of the fourth synapomorphy teeth multicuspid, pedunculate, largely expanded and distally compressed - was found by Malabarba (1998) to be apomorphically reversed in M. uruguayanae, which presents conical teeth. The only other cheirodontines that present conical teeth are included in a monophyletic clade hypothesized by Bührnheim et al. (2008), belonging to the tribe Cheirodontini, and composed by Amazonspinther dalmata Bührnheim, Carvalho, Malabarba \& Weitzman, plus Spintherobolus species.

When describing some deviations from the cheirodontine generalized type, Eigenmann (1915) included Macropsobrycon in a group of genera with "three-pointed" teeth (p. 7), but in his picture of the types and variation of teeth in the Cheirodontinae (fig. 1, a-b ${ }^{1}$, p. 9), and in the description of the genus Macropsobrycon and its type species (p. 48), Eigenmann only mentioned the presence of conical teeth, with few of them bearing a lateral notch. Géry (1960, $1965,1972,1973$, and 1977) as well as Malabarba (1998, Ch. 56-0) considered that M. uruguayanae bears conical teeth. From 34 c\&s specimens of M. uruguayanae only two relatively large females (MCP 18365, 35.2 mm SL; MCP 11939, 32.4 mm 
SL) presented one single tooth on the dentary bearing an evident lateral notch; the remaining specimens presented conical teeth both on the dentary and premaxilla.

Mature males of Macropsobrycon uruguayanae present several modifications associated with the secondary sexual system, such as presence of gill gland, caudal-fin hooks, and hypertrophy of the last body scales over the base of the caudal-fin rays. The occurrence of elaborate structural modifications associated with sexual dimorphism was hypothesized by Weitzman \& Malabarba (1998) to be directly related to the existence of complex courtship behavior and/or the process of insemination. Macropsobrycon uruguayanae was recognized as an inseminating species by Burns et al. (1997), its sperm ultrastructure studied by Oliveira et al. (2008), and its gill gland development and reproductive biology described by Azevedo et al. (2010), but nothing is known about its courtship behavior.

Among characids, the presence of modified scales in the caudal fin is a feature known to occur in the inseminating species of the Stevardiinae, and Compsurini. Notwithstanding, recent morphological and molecular based phylogenies encompassing representatives of these groups have shown that they belong to distinct and distant evolutionary lineages in Characidae, denoting that both the modified caudal-fin structures and the associated inseminating process are homoplastic and have evolved independently in Compsurini and in some Stevardiinae representatives (Malabarba, 1998; Weitzman \& Menezes, 1998; Malabarba \& Weitzman, 2003; Calcagnotto et al., 2005; Weitzman et al., 2005; Menezes et al., 2008; Mirande, 2009, 2010; Javonillo et al., 2010).

Among the Compsurini fishes, Compsura heterura Eigenmann, "Compsura" gorgonae (Evermann \& Goldsborough), "Odontostilbe" dialeptura (Fink \& Weitzman), "O". mitoptera (Fink \& Weitzman), Saccoderma hastata (Eigenmann), and S. melanostigma Schultz, present modified caudal-fin scales. "Odontostilbe" dialeptura and "O". mitoptera have a cluster of small scales over the base of the middle caudal-fin rays (Fink \& Weitzman, 1974: fig. 3). These scales are feebler than the body scales, and are usually missing at specimens from museums. In Compsura species, Saccoderma hastata and S. melanostigma the modified scales are as strong as the body scales and firmly attached to the skin. These scales are placed at the lower lobe of the caudal fin, and compose one or more pouches associated to the hypertrophied tissue. The modified scales of $M$. uruguayanae are also present over the lower caudal-fin lobe, but they do not form any kind of pouch structure even on fully mature males. The largest scale of M. uruguayanae (Fig. 6b) has several radii; it is feebler than the common body scales, and generally is missing on preserved mature males. This scale enlargement associated to the modified shape of the scale of the lower caudal-fin lobe of $M$. uruguayanae is unique and autapomorphic for the genus and species.

Among cheirodontines, the presence of hooks at the caudal-fin rays is a character shared by most compsurin species including Macropsobrycon uruguayanae,
Acinocheirodon melanogramma, "Odontostilbe" dialeptura, Saccoderma hastata, and S. melanostigma. Mature males of $M$. uruguayanae have hooks and spinelets from the $12^{\text {th }}$ to the $18^{\text {th }}$ caudal-fin rays. The hooks found on the $12^{\text {th }}$ and $13^{\text {th }}$ principal caudal-fin rays are restricted to the terminal branches of these rays, they are large, thick, retrorse, laterally and sometimes ventrally curved, and directed toward the caudalfin base, while the spinelets are fragile and distributed along most length of the $14^{\text {th }}$ to $18^{\text {th }}$ principal caudal-fin rays (Figs. 4 and 5). The presence of these spinelets is unique among compsurins and an autapomorphy of $M$. uruguayanae.

Possible homologies of the hooks found in the $12^{\text {th }}$ to the $13^{\text {th }}$ caudal-fin rays of Macropsobrycon uruguayanae with remaining compsurin genera deserve further investigation, considering they vary in shape, size, and location. Mature males of Acinocheirodon melanogramma also present distinct hooks on the distal portion of $13^{\text {th }}$ and $14^{\text {th }}$ caudal-fin rays, but in this case, the caudal-fin hooks are longer, straight, angled dorsoanteriorly, and are borne by thickened ray segment (Malabarba \& Weitzman 1999: p. 416-418, figs. 4-6). The caudal-fin hooks in "Odontostilbe" dialeptura are distributed from the $12^{\text {th }}$ to the $15^{\text {th }}$ principal rays and in Saccoderma hastata, and S. melanostigma from the $13^{\text {th }}$ to the $18^{\text {th }}$ rays (rarely on $19^{\text {th }}$ ), and on these species the hooks can be found along all the length of the rays. They have similar size all over the fin and are dorsoanteriorly directed in "Odontostilbe" dialeptura, and mostly retrorse and anteriorly directed in Saccoderma species. Besides this variation, the shape and distribution of the hooks in M. uruguayanae differ from all other compsurin.

The variation of color patterns among cheirodontines is not great. In spite of some species presenting notable marks on the dorsal fin such as Amazonspinther dalmata, Odontostilbe pequira (Steindachner, 1882), Prodontocharax melanotus Pearson, 1924 and Serrapinnus notomelas (Eigenmann, 1915), or on the anal fin as some species of Spintherobolus Eigenmann, 1911 and Amazonspinther dalmata, most of the cheirodontines present basically a narrow longitudinal line at the body, a caudal spot, and scattered melanophores all over the dorsal, anal and caudal fins. As stated by Malabarba (1998), all the Compsurini share a dark distal border on the anal fin due to the higher concentration or melanophores in that region, a character more conspicuous on fully mature males. Eigenmann (1915) cited the presence of "an ovate dark spot on middle caudal peduncle" for Macropsobrycon uruguayanae, but neglects the small dark bars present between the first two unbranched dorsal-fin rays, and between the bases of the last two unbranched anal-fin rays (see color pattern description). The presence of these small spots on the anteriormost dorsaland anal-fin rays is apomorphic, but it is also found in other Compsurini from South America. Acinocheirodon melanogramma and Compsura heterura also have a dark bar between the first and second unbranched rays of dorsal and anal fin from about the distal tip of first to about midlength of the second fin ray. Kolpotocheirodon figueiredoi also 
present a dorsal-fin spot, but in this species it is located posteriorly, between midlengths of the first and second, and second and third branched rays; and both Kolpotocheirodon species possess a dark bar at the midlength of the first branched anal-fin ray (Malabarba \& Weitzman, 2000; Malabarba et al., 2004). None of the trans-Andean Compsurini species possesses any conspicuous bars as found on cisAndean species.

Another peculiar color pattern of Macropsobrycon uruguayanae is the presence of a high concentration of melanophores anteriorly to- and around the pelvic-fin insertion in mature males. The melanophores are mainly scattered over the pelvic-girdle muscles, in a very similar pattern to that found in Kolpotocheirodon figueiredoi, as described by Malabarba et al. (2004: fig. 8). Mature males of Kolpotocheirodon theloura also present the respective ventral region darker than in females and immature males, but in this species the melanophores seem to be distributed along the contacting edge between the muscles arrector ventralis pelvicus and abductor superficialis pelvicus.

We found that "Macropsobrycon" xinguensis lacks the synapomorphies discussed above for Cheirodontinae, Compsurini, and even those characters shared between $M$. uruguayanae and the other genera of Compsurini. "Macropsobrycon" xinguensis also lacks all autapomorphies proposed for Macropsobrycon, and thus does not belong to this genus, tribe and subfamily. Relationships of " $M$ ". xinguensis will be dealed in a separate paper, with a new set of comparative taxa and characters than those discussed herein.

Macropsobrycon uruguayanae is the only Compsurini representative to occur in the Uruguay and laguna dos Patos basins. Other cheirodontines present in these systems are: Cheirodon ibicuhiensis Eigenmann, 1915, C. interruptus (Jenyns, 1842), Heterocheirodon yatai (Casciotta, Miquelarena \& Protogino, 1992), H. jacuiensis Malabarba \& Bertaco, 1999, Odontostilbe pequira (Steindachner, 1882), and Serrapinnus calliurus (Boulenger, 1900) (Malabarba, 2003, 2007). These Cheirodontini species can be readily distinguished from $M$. uruguayanae by the presence of expanded and distally compressed pedunculate teeth, and absence of any modifications at the caudal fin, like hooks or hypertrophied scales.

Comparative material. Acinocheirodon melanogramma: ANSP 176238, paratypes, 7, 21.9-26.2 mm SL, Brazil, Minas Gerais, rio Jequitaí drainage. Aphyodite grammica: FMNH, holotype, 24.3 mm SL, Guiana, Konawaruk. MZUSP 29874, 20, 21.9-26.9 mm SL, Brazil, rio Negro. Brittanichthys axelrodi: MCP 14931, 17, 16.3$22.2 \mathrm{~mm}$ SL, 3 c\&s, Brazil, Boa Vista, rio Negro. Cheirodon australe: USNM 84317, paratypes, 12, 28.4-49.8 mm SL, Chile, Los lagos Region at Puerto Varas. Cheirodon dialepturus: USNM 208524, holotype, $26.8 \mathrm{~mm}$ SL, Panama, Veraguas, rio San Pedro basin. Cheirodon galusdae: USNM 84319, paratypes, 10, 30.6-52.3 mm SL, Chile, Rio Locomilla at San Xavier. Cheirodon gorgonae: USNM 64094, holotype, $22.1 \mathrm{~mm}$ SL, Panama, Canal Zone, small seepage pool below spillway of the reservoir dam at Gorgona. Cheirodon kiliani: USNM 227310, paratype, 1, $25.2 \mathrm{~mm}$ SL. Valdivia-Chile, rio Cau-Cau. Cheirodon microdon: FMNH 57867, holotype, 32.2 mm SL, Brazil, Caceres, rio Ibicuhy. Cheirodon micropterus: CAS 59780, holotype, 23.9 mm SL, Brazil, Pará, rio Amazonas drainage at Santarém. Cheirodon mitopterus: USNM 208539, holotype, $34.6 \mathrm{~mm}$ SL, Panama, Cocle, rio Tucue, tributary of rio Cocle del Norte. Cheirodon notomelas: FMNH 57829, holotype, $28.2 \mathrm{~mm}$ SL, Brazil, Miguel Calmone. Cheirodontops geayi: USNM 121507 , holotype, $35.5 \mathrm{~mm}$ SL, Venezuela, Estado de Aragua, rio Guarico. Compsura heterura: FMNH 57825, holotype, 28.7 mm SL, Brazil, rio Itapicuru, Queimadas. Holesthes heterodon: CAS 117522 , paratypes, 4, 32.2-36.5 mm SL, Brazil, Minas Gerais, rio Grande, Jaguara. Leptobrycon jatuaranae: MCP 14936, 17, 20.8-25.1 mm SL, 3 c\&s, Brazil, Amazonas, rio Negro. "Macropsobrycon" xinguensis: MCP 34546, 26, 18.6-29.1 mm SL, 3 c\&s, Brazil, Mato Grosso, Nova Canaã do Norte, rio Kaiapá. Microschemobrycon guaporensis: FMNH 57926, holotype, 29.1 mm SL, Brazil, Maciel, rio Guaporé. Odontostilbe hastatus: FMNH 56383, holotype, 30.2 $\mathrm{mm}$ SL, Colombia, Soplaviento. Oligobrycon microstomus: holotype, $31.0 \mathrm{~mm}$ SL, Brazil, Jacarehy on rio Parahyba. Oxybrycon sp.: MCP 33105, 8, 13.7-14.9 mm SL, 2 c\&s, Venezuela, Titi Lagoon, upper Orinoco basin. Parecbasis cyclolepis: FMNH 56677, holotype, $56.3 \mathrm{~mm}$ SL, Brazil, rio Madeira. MZUSP 26146, 7, 40.3-53.5 mm SL, Peru, Ucayali, río Ucayali. Pristella aubynei: FMNH 52698, holotype, $34.9 \mathrm{~mm}$ SL, British Guiana. Prodontocharax alleni: CAS 117472, holotype, $32.8 \mathrm{~mm} \mathrm{SL}$, Peru, Ucayali, rio Amazonas basin. Prodontocharax melanotus: CAS 59793, holotype, $44.9 \mathrm{~mm}$ SL, Bolivia, La Paz, rio Amazonas drainage at Tumupasa. Pseudocheirodon affinis: CAS 117516, paratype, 10, 32.1-35.4 mm SL, Panama, río Gatun, at Gatun. Saccoderma melanostigma: USNM 121519, holotype, $26.7 \mathrm{~mm}$ SL, Venezuela, río San Juan, South of Mene Grande. Spintherobolus broccae: FMNH 58864, paratype, 1, $18.7 \mathrm{~mm}$ SL, Brazil, Rio de Janeiro. Spintherobolus papilliferus: FMNH 104802, holotype, 32.9 mm SL, Brazil, São Paulo, Alto da Serra. Thrissobrycon pectinifer: SU 16944, holotype, $26.8 \mathrm{~mm} \mathrm{SL}$, Brazil, Cucuhy, rio Negro. MCP 14932, 12, 26.4-30.2 mm SL, 3 c\&s, Brazil, rio Arirara.

\section{Acknowledgements}

We are thankful to Carlos A. Lucena (MCP), Flávio C. T. Lima, Osvaldo Oyakawa (MZUSP), Mary Anne Rogers, Kevin Swagel (FMNH), Richard Vari, Jerry Finan, Jeffrey Clayton (NMNH), John Lundberg, Mark Sabaj-Pérez (ANSP), David Catania and Jon D. Fong (CAS) for loan of specimens, and for museum and technical support. We also thank three anonymous referees that greatly improved this manuscript. FCJ is supported by a CAPES doctoral fellowship, and was supported by a "Doutorado Sanduíche no Exterior" fellowship by the CNPq (201753/2008-1). LRM research is supported by CNPq (479412/2008-1).

\section{Literature Cited}

Azevedo, M. A., L. R. Malabarba \& J. R. Burns. 2010. Reproductive biology and development of gill glands in the inseminating characid, Macropsobrycon uruguayanae Eigenmann, 1915 (Cheirodontinae: Compsurini). Neotropical Ichthyology, 8(1): 87-96. 
Bührnheim, C. M., T. P. Carvalho, L. R. Malabarba \& S. H. Weitzman. 2008. A new genus and species of characid fish from the Amazon basin - the recognition of a relictual lineage of characid fishes (Ostariophysi: Cheirodontinae: Cheirodontini). Neotropical Ichthyology, 6(4): 663-678.

Bührnheim, C. M. \& L. R. Malabarba. 2006. Redescription of the type species of Odontostilbe Cope, 1870 (Teleostei: Characidae: Cheirodontinae), and description of three new species from the Amazon basin. Neotropical Ichthyology, 4(2): 167-196.

Burns, J. R., S. H. Weitzman, K. R. Lange \& L. R. Malabarba. 1998. Sperm ultrastructure in characid fishes (Teleostei: Ostariophysi). Pp. 235-244. In: Malabarba, L. R., R. E. Reis, R. P. Vari, Z. M. S. Lucena, \& C. A. S. Lucena (Eds.). Phylogeny and Classification of Neotropical Fishes. Porto Alegre, Edipucrs, 603p.

Burns, J. R., S. H. Weitzman \& L. R. Malabarba. 1997. Insemination in eight species of cheirodontine fishes (Teleostei: Characidae: Cheirodontinae). Copeia, 1997: 433-438.

Calcagnotto, D., S. A. Schaefer \& R. DeSalle. 2005. Relationships among characiform fishes inferred from analysis of nuclear and mitochondrial gene sequences. Molecular Phylogenetics and Evolution, 36(1): 135-153.

Demonte, L. D. \& J. D. Arias. 2005. Ictiofauna de afluentes de los ríos Paraná y Uruguay em la Província de Entre Ríos, Argentina. Temas de la Biodiversidad del Litoral II, Insugeo Miscelanea, 14: 355-366.

Eigenmann, C. H. 1915. The Cheirodontinae, a subfamily of minute characid fishes of South America. Memoirs of the Carnegie Museum, 7(1): 1-99.

Fink, W. L. \& S. H. Weitzman. 1974. The so-called Cheirodontin fishes of Central America with descriptions of two new species (Pisces: Characidae). Smithsonian Contributions to Zoology, 172: 1-46.

Géry, J. 1960. Contributions to the study of characoid fishes. II. The generic position of Hyphessobrycon innesi and Cheirodon axelrodi, with a review of the morphological affinities of some Cheirodontinae (Pisces - Cypriniformes). Bulletin of Aquatic Biology, 2(12): 1-18.

Géry, J. 1965. Poissons characoides sud-americains du Senckenberg Museum, II. Characidae et Crenuchidae de l'Igarape Preto (Haute Amazonie). Senckenbergiana Biologica, 46(1): 11-45.

Géry, J. 1972. Corrected and supplemented descriptions of certain Characoid fishes described by Henry W. Fowler, with revisions of several of their genera. Studies on the Neotropical Fauna, 7: $1-35$.

Géry, J. 1973. New and little-known Aphyoditeina (Pisces, Characoidei) from the Amazon basin. Studies on the Neotropical Fauna, 8: 81-137.

Géry, J. 1977. Characoids of the world. T. F. H. Publications, Neptune City, 672p.

Gonçalves, T. K., M. A. Azevedo, L. R. Malabarba \& C. B. Fialho. 2005. Reproductive biology and development of sexually dimorphic structures in Aphyocharax anisitsi (Ostariophysi: Characidae). Neotropical Ichthyology, 3(3): 433-438.

Hammer, Ø. \& D. A. T. Harper. 2005. PAST: Paleontological Statistics Software Package for Education and Data Analysis, version 1.93. Available at: http://folk.uio.no/ohammer/past.

Javonillo, R., L. R. Malabarba, S. H. Weitzman \& J. R. Burns. 2010. Relationships among major lineages of characid fishes (Teleostei: Ostariophysi: Characiformes), based on molecular sequence data. Molecular Phylogenetics and Evolution, 54: 498-511.
Malabarba, L. R. 1998. Monophyly of the Cheirodontinae, characters and majors clades (Ostariophysi: Characidae). Pp. 193-233. In: Malabarba, L. R, R. E. Reis, R. P. Vari, Z. M. S. Lucena \& C. A. S. Lucena (Eds.). Phylogeny and Classification of Neotropical Fishes. Porto Alegre, Edipucrs, 603p.

Malabarba, L. R. 2003. Subfamily Cheirodontinae (Characins, tetras). Pp. 215-221. In: Reis, R. E., S. O. Kullander \& C. J. Ferraris (Eds.). Check list of the freshwater fishes of South and Central America. Porto Alegre, Edipucrs, 729p.

Malabarba, L. R. 2007. Family Characidae: Cheirodontinae. Pp. 36-38. In: Buckup, P. A., N. A. Menezes \& M. S. Ghazzi. Catálogo das espécies de peixes de água doce do Brasi. Série Livros 23 Museu Nacional, Universidade Federal do Rio de Janeiro, Rio de Janeiro, 195p.

Malabarba, L. R. \& F. C. T. Lima \& S. H. Weitzman. 2004. A new species of Kolpotocheirodon (Teleostei: Characidae: Cheirodontinae: Compsurini) from Bahia, northeastern Brazil, with a new diagnosis of the genus. Proceedings of the Biological Society of Washington, 117(3): 317-329.

Malabarba, L. R. \& S. H. Weitzman. 1999. A new genus and species of South American fishes (Teleostei: Characidae: Cheirodontinae) with a derived caudal fin, including comments about inseminating cheirodontines. Proceedings of the Biological Society of Washington, 112(2): 410-432.

Malabarba, L. R. \& S. H. Weitzman. 2000. A new genus and species of inseminating fish (Teleostei: Characidae: Cheirodontinae: Compsurini) from South America with uniquely derived caudal-fin dermal papillae. Proceedings of the Biological Society of Washington, 113(1): 269-283.

Malabarba, L. R. \& S. H. Weitzman. 2003. Description of a new genus with six new species from southern Brazil, Uruguay and Argentina, with a discussion of a putative characid clade (Teleostei: Characiformes: Characidae). Comunicações do Museu de Ciências e Tecnologia, PUCRS, Série Zoologia, 16(1): 67-151.

Menezes, N. A., A. C. Ribeiro, S. H. Weitzman \& R. Torres. 2008. Biogeography of Glandulocaudinae (Teleostei: Characiformes: Characidae) reviewed: phylogenetic patterns, historical geology and genetic connectivity. Zootaxa, 1726: 33-48.

Miquelarena, A. M., J. E. Mantinián \& H. L. López. 2008. Peces de la Mesopotamia Argentina (Characiformes: Characidae: Cheirodontinae). Temas de la Biodiversidad del Litoral III, Insugeo - Miscelanea, 17: 51-90.

Mirande, J. M. 2009. Weighted parsimony phylogeny of the family Characidae (Teleostei: Characiformes). Cladistics, 25: 574-613.

Mirande, J. M. 2010. Phylogeny of the family Characidae (Teleostei: Characiformes): from characters to taxonomy. Neotropical Ichthyology, 8(3): 385-568.

Oliveira, C. L. C., J. R. Burns, L. R. Malabarba \& S. H. Weitzman. 2008. Sperm ultrastructure in the inseminating Macropsobrycon uruguayanae (Teleostei: Characidae: Cheirodontinae). Journal of Morphology, 269: 691-697.

Pecio, A., J. R. Burns \& S. H. Weitzman. 2007. Comparison of spermiogenesis in the externally fertilizing Hemigrammus erythrozonus and the inseminating Corynopoma riisei (Teleostei: Characiformes: Characidae). Neotropical Ichthyology, 5(4): 457470.

Quagio-Grassiotto, I., M. C. Gameiro, T. Schneider, L. R. Malabarba \& C. Oliveira. 2003. Spermiogenesis and spermatozoa ultrastructure in five species of the Curimatidae with some considerations on spermatozoal ultrastructure in the Characiformes. Neotropical Ichthyology, 1(1): 35-45. 
Reis, R. E., S. O. Kullander \& C. J. Ferraris (Eds.). 2003. Check List of the Freswater Fishes of South and Central America. Porto Alegre, Edipucrs, 729p.

Strauss, R. E. 1985. Evolutionary allometry and variation in body form in the South American catfish genus Corydoras (Callichthyidae). Systematic Zoology, 34: 381-396.

Taylor, W. R. \& G. C. van Dyke. 1985. Revised procedures for staining and clearing small fishes and other vertebrates for bone and cartilage study. Cybium, 9(2): 107-119.

Weitzman, S. \& L. R. Malabarba. 1998. Perspectives about the phylogeny and classification of the Characidae (Teleostei: Characiformes). Pp. 161-170. In: Malabarba, L. R., R. E. Reis, R. P. Vari, Z. M. S. Lucena \& C. A. S. Lucena (Eds.). Phylogeny and Classification of Neotropical Fishes. Porto Alegre, Edipucrs, $603 p$.

Weitzman, S. H. \& N. A. Menezes. 1998. Relationships of the tribes and genera of Glandulocaudinae (Ostariophysi: Characiformes: Characidae) with a description of a new genus, Chrysobrycon. Pp. 171-192. In: Malabarba, L. R., R. E. Reis, R. P. Vari, Z. M. Lucena \& C. A. Lucena (Eds.). Phylogeny and Classification of Neotropical Fishes. Porto Alegre, Edipucrs, $603 p$.

Weitzman, S. H., N. A. Menezes, H-G. Evers \& J. R. Burns. 2005. Putative relationships among inseminating and externally fertilizing characids, with a description of a new genus and species of Brazilian inseminating fish bearing an anal-fin gland in males (Characiformes: Characidae). Neotropical Ichthyology, 3(3): 329-360.

Accepted March 1, 2011

Published June 30, 2011 